\title{
CSALÁDTÖRTÉNETEK HIÁNYA, TÖRTÉNELEMTŐL ELIDEGENEDETT NEMZEDÉK, ÚJ IFJÚSÁGI SEBEZHETŐSÉGEK ÉS TÖRTÉNELEMTANÍTÁS
}

\section{LACK OF FAMILY HISTORIES, GENERATIONS ALIENATED FROM HISTORY, NEW VULNERABILITIES OF YOUTH, AND HISTORY EDUCATION}

\author{
Jancsák Csaba \\ PhD, MTA-SZTE Elbeszélt Történelem és Történelemtanítás Kutatócsoport, Szeged \\ jancsak@jgypk.szte.hu
}

ÖSSZEFOGLALÁS

A tanulmány az MTA-SZTE Elbeszélt Történelem és Történelemtanítás kutatócsoport keretében folytatott tantárgy-pedagógiai kutatások foglalatát mutatja be. Kiinduló állításunk szerint a legutóbbi években a gyermekek és fiatalok életvilágát érintő társadalmi, gazdasági, technológiai, életmódbeli és civilizációs változások eredményeként formálódott a történelem és állampolgári ismeretek tantárgy felé megfogalmazódó társadalmi elvárások alkotta szerepkomplexum. Az új szerepelvárások részben a cselekvő és tudatos állampolgári szerepekre érzékenyítésben, az állampolgári nevelésben jelentek meg, részben a kritikai gondolkodás és a történelmi gondolkodás fejlesztése terén, részben pedig a hagyományos, európai transztörténelmi értékek és a kollektív emlékezet megőrzése terén. 32 iskolai osztályban tartott történelemórák előtt és után, összesen 540 fő kérdőíves vizsgálatával, továbbá tizenkét fókuszcsoportban zajlott kutatásaink során azt vizsgáltuk, hogy három történelmi mérföldkő (Magyarország második világháborús szerepvállalása, a magyarországi holokauszt, valamint az 1956-os forradalom és szabadságharc) esetében a csoport által kifejlesztett tanórák milyen hozzáadott értéket hordoznak a szemtanúkkal (résztvevőkkel, elszenvedőkkel, szereplőkkel) készült videóinterjúknak a történelemtanításba való (tantárgy-pedagógiai tudományos eredmények által megalapozott) bekapcsolása által.

\section{ABSTRACT}

The paper presents an encapsulation of the subject-teaching pedagogy research conducted by the MTA-SZTE Oral History and History Education Research Group. Our premise is that the role complex that society's expectations assign to History and Civic Education as a school subject results from social, economic and technological changes as well as changes in lifestyle and civilisation, which have been affecting children's and youth's world of life in recent years. The new role expectations partly appear as sensitization towards the roles of active and conscious citizenship and as civic education, and they can partly be detected in the development of critical thinking and historical thinking and in the preservation of traditional, European transhistorical values and collective memory. 32 school classes participated in our research, where we admin- 
istered questionnaires for 540 subjects and conducted 12 focus group interviews before and after history lessons. We investigated what added values the teaching materials developed by our group bring on three historical milestones (Hungary's engagement in World War II, the Hungarian Holocaust and the 1956 Revolution and War of Independence) incorporating video interviews with eyewitnesses (participants, victims, actors) in a way that is supported by research results of subject-teaching pedagogy.

Kulcsszavak: történelemtanítás, elbeszélt történelem, új ifjúsági sebezhetőségek, kritikai gondolkodás, történelmi gondolkodás

Keywords: history education, oral history, new vulnerabilities of youth, critical thinking, historical thinking

A legutóbbi évek ifjúságkutatásaiból kirajzolódik, hogy a családi körben beszélgetéssel töltött idő a reggeli készülődésre és az esti időszakra szükült össze. Ezen idősávokban az iskolába indulással és az esti nyugovóra téréssel kapcsolatos rituálék állnak a családi együttlét középpontjában. A családtörténeteknek a nagyszülők és a szülők általi hagyományos elbeszélési keretei eltűnnek a családi együttlétekből. Ennek okát nemcsak a többgenerációs együttélési modell megszünésében lelhetjük meg, hanem abban is, hogy a kilencvenes évektől kezdődően a szülői generációk esetében kitolódott a gyermekvállalás életkora, és a múlt eseményei iránt fogékony tizenévesek legtöbbjének elérhetetlen a nagyszülői történetmesélés. Fokozza ezt a hiányt a történelmi múlt egyes eseményeinek már a szülői és nagyszülöi generációk közötti „kibeszéletlensége” is. Az a három tanagyag-téma, amellyel csoportunk kutatásait folytatta, Magyarország második világháborús szerepvállalása, a magyarországi holokauszt vagy az 1956-os forradalom olyan történelmi események, amelyek annak ellenére ilyen kibeszéletlen elemei történelmi emlékezetünknek, hogy az elszenvedők, áldozatok, az események részesei, a szemtanúk közül még jó néhány személy jelen van korunkban, jelen volt a közelmúltban mint a dédszülők, illetve a nagyszülők generációjának tagja. A kibeszéletlenséget fokozza a szakmai diskurzusok, a szakértői párbeszéd hiánya: a „megbeszéletlenség”. Fokozza továbbá az, hogy a szülői generáció nagy része sem hallotta már a családtörténeteket, de ha igen, akkor sincs mód, nincs idő - napjaink hajszoltsága okán, mint fentebb leírtuk - a történetmesélésre. Mindezek után nem meglepő, hogy kutatásainkból (Jancsák, 2019a, 2019b) egy, a történelmi múlttól izolálódott, a történelemtől elidegenedett nemzedék képe rajzolódik ki előttünk, amikor a mai 14-18 éves fiatalokat kutatjuk.

A kollektív emlékezet megőrzésének legfőbb szereplöje a család. Az idősebb generációk által a fiatalabb generációknak elbeszélt történelem, a személyes nar- 
ratívák, tehát az elbeszélésnek az a vetülete, amikor a személyes történet és a történelem egy idővonalon párhuzamosan fut, az értékhordozó szimbólumokon keresztül nemcsak a történéseknek az újabb generációkra való átörökítését, hanem a mindennapi életben való eligazodást, iránymutatást jelentő társadalmi értékek megörzését is támogatja.

Felerősödtek azon tényezők, amelyek arra utalnak, hogy az Ulrich Beck által az évezred első évtizedében leírt világkockázati társadalomban élünk (Beck, 2007). Korunk jellemzője a közmegegyezésen alapuló normák és a társadalmi értékek válsága okozta instabilitás és elbizonytalanodás. A gazdasági és politikai válságok, az új migrációs áramlatok, a politikai populizmus erősödése és a technológiai változások új sebezhetőségeket okoztak gyermek és ifjúsági korosztályok számára, úgymint a szabadság, a szolidaritás, az empátia, az autonómia, a felelősség értékeinek válsága, azaz az univerzális humanista értékek válsága, továbbá a post-truth korszak manipulációinak, azaz a félelemiparnak való kitettség.

A tömegmédia befolyásoló hatása a fiatalok gondolkodására egyeduralkodóvá vált (M. Fazekas-Czachesz, 2011; Gábor, 2012; Jancsák, 2013; Galán, 2014; Székely-Szabó, 2017; Zsolnai, 2017; Kiss-Pikó, 2018). A web2 és az okoseszközök megjelenésével, illetve a családban beszélgetéssel töltött idő csökkenésével együtt csökkent a család hatása a fiatalok gondolkodására, értékorientációira. A gyermekek számára felértékelődött a kortárscsoportok és a virtuális ifjúsági közösségek szerepe. A legutóbbi években pedig a valós (face-to-face) baráti közösségek helyét átvették a virtuális ifjúsági értelmező közösségek és az egyes személyt irányító influenszerek. Mindezek együtt azzal a következménnyel járnak Magyarországon, hogy az iskoláskorú gyermekek úgy használják alapvetó információforrásként az internetet és a közösségi médiát, hogy bennük jó táptalajra találnak a hoaxok, tévképzetek, manipulatív információcsoportosítások, hamis tényállítások.

Ezt a sebezhetőséget felesősíti a fokozódó izolálódás, begubózás jelensége, amely a gyermek és fiatal személy kilépését jelenti a hagyományos értelmező közösségek (család, kortárs baráti társaságok) szürőrendszerének a tévképzetek terjedését és a manipulációt korlátozó hatása alól.

Ezen problémák mint kiterjesztett szerepelvárások jelennek meg a történelemtanítás és a történelemtanárok előtt. A kiterjesztett szerepelvárások az iskola hagyományos szerepein (esetünkben a történelem tanításán) felüli szocializációs feladatokat jelentenek. Torsten Husén (1997) mutatta ki, hogy míg a korábbi generációk esetében a szocializáció jellemzően az iskolán kívüli terekben és jellemzően a családban, a rokoni, illetve ismerősi körökben zajlott, ma a családi-rokoni körben egyre kevésbé megvalósuló szocializációs funkciók ellátását az iskolától (és a pedagógusoktól) várja a társadalom. Ezek: a társadalmi szerepekre való felkészítés körébe tartozó nevelési feladatok, mint a személyes felelősségtudatra, toleranciára, empátiára, szolidaritásra, együttmüködésre való képességek, kom- 
petenciák fejlesztése. Továbbá - az előbbieken felül, a web2 kiterebélyesedésével együtt - megjelent az információk gyüjtésére, szelektálására és értelmezésére, a megalapozott véleményalkotásra felkészítő szocializációs szerepek, illetve a társadalmi értékek és normák iránti érzékenyítés, valamint az állampolgári kompetenciák fejlesztése.

Ám, mivel a gyermekek értelmező közösségei körében nem folyik diskurzus a történelmi múltról, és a kollektív emlékezetünk egyes elemei (amelyek egyúttal értékhordozó szimbólumok is) elhalványulnak, ezért a történelmi mérföldkövek az iskolai oktatásban mélyebb háttértudás és attitüdök nélküli szöveggé válnak, és kiüresednek (tanuld meg a „vastag betüs mondatokat”).

A magyarországi oktatási rendszer nem készült fel az e jelenségekre adott válaszokra. Ez igaz az állampolgári nevelés feladatát az oktatási dokumentumok (Nemzeti alaptanterv, NAT) által ellátó történelem és állampolgári ismeretek tantárgyra is, amelynek legföbb feladata lenne a közoktatás 8. és 12. osztályában (a 14 és a 18 éves diákok) esetében a tudatos, cselekvő állampolgárrá érzékenyítés (nevelés).

Korábbi kutatásaink alapján az rajzolódott ki előttünk (Jancsák 2018, 2019a, 2019b), hogy (1) a történelemtanítás tankönyvvezéreltsége okán kevésbé látja el a nevelő funkcióját, (2) a történelemtanár-képzésben az állampolgári nevelés kérdéseire reflektáló tartalmak nincsenek jelen, (3) a tanárok nem érzik magukat felkészültnek az állampolgári nevelés feladatára.

Az oktatáskutatásoknak a történelemtanítás tárgyában született nemzetközi dimenziójában alapvetően két szemléletmód nyert teret az utóbbi években. Az egyik megközelítés szerint a kritikai gondolkodás fejlesztésének és a forráselemzésnek kell a történelemtanítás krédójában állnia (Husbands, 1996; Havekes et al., 2010; Maggioni, 2010; Keating-Sheldon, 2011; Körber, 2011; Tally-Goldenberg, 2005; Kaposi, 2017; Metzger-McArthur, 2018), a másik a történelemtanítás kollektív emlékezetet megőrző szerepét emeli ki (Megill, 1994; Bage, 1999; Fisherné, 2010; Seixas, 2016). Azonban oktatásszociológiai nézőpontból szemlélve a kérdést, a társadalmi/történelmi környezetet megrajzoló (történész-kutatók által megvitatott, lektorált és a forráselemzést és forráskritikát megalapozó) szaktárgyi tudáselemek ismerete nélkül csak üres fecsegéssé válhat a történelmi források értelmezése, a kollektív emlékezetbe pedig kritikai gondolkodás nélkül könynyen kerülhetnek manipulatív tartalmak, fake news, hoaxok. A csoport kutatási eredményei kapcsán amellett érvel, hogy a fenti két nézetrendszer együttese az, amely komoly hozzáadott értéket jelent a jelenleg iskolapadban nevelődő generációk későbbi állampolgári életvilága szempontjából, amikor a történelemtanítás (1) a társadalmi értékeket magáénak valló, (2) múltunk-kultúránk elemeit ismerő és alkotó módon értelmező, (3) tudatos és cselekvő állampolgári szerepre készíti fel a fiatalokat. 
Kutatócsoportunk három téma (Magyarország részvétele a második világháborúban, a magyarországi holokauszt és az 1956-os forradalom) esetében fejlesztett ki szemtanúkkal készült videóinterjú-részleteket alkalmazó tanórákat, majd vizsgálta (32 iskolai osztályban tartott tanórák előtt és után, összesen 540 fő kérdőíves vizsgálatával, továbbá 12 fókuszcsoportos vizsgálat során) a beválást, valamint a diákokra kifejtett hatásokat (új ismeretszerzés, tárgyi tudás bővülése, ismeretelmélyítés, ismeretek rendszerezése és az érzelmi komponensek esetében egyaránt), majd ezen kutatási eredmények alapján fejlesztettük tovább a tanórák tartalmát. Az ilyen módon átdolgozott tanórákat videódokumentációval rögzítettük, és elemeztük az alkalmazott módszerek hatékonyságát, illetve a tanárok és diákok megszólalásait, beszéd-cselekvéseiket. A tanórák egy része a szemtanúkkal készült videóinterjú-részletek alapján célozta az empátia, a felelősség, a szolidaritás, a szabadság, a demokrácia, a tolerancia értékeinek megjelenítését és az ezzel kapcsolatos attitüdökre érzékenyítést. Az új tanórák másik része pedig a történelmi gondolkodás fejlesztését célozta, itt a személyes történelem mint narratív történetforma és forrás jelent meg.

A szemtanúkkal készült videóinterjú-részleteket használó tanórák fontos hozzáadott értéke a kritikai gondolkodás fejlesztése, a nemzetközi szakirodalomban historical thinkingnek nevezett tényezö (Wineburg, 2001; Kadriye-Seixas, 2015; Kelly, 2018), amely a történészi (kutatói) gondolkodásra vezet rá az egyes tényállítások esetében, és a forráskritika, forráselemzés, forráskezelés módszereit és szemléletmódját mutatja be, illetve fejlesztheti olyan jártassággá, amely például a jelenkortörténet és a napi közéleti/politikai témák kapcsán támogatja az információk értelmezését, a háttér feltárására és az esetleges manipulatív tartalmak kiszürésére vonatkozó képességeket. Ugyanakkor eredményeink azt is mutatják, hogy a videóinterjú-források tanórai alkalmazása további hozzáadott értéket jelent a pedagógiai nevelési célokat követő attitüdök kialakítása és a társadalmi értékek generációk közötti átadása során is. Az előbbiek segítik a történelem tanítását/tanulását, de nemcsak ezért fontosak, hanem azért is, mert az értéktelített nevelés úgy alakít ki tudatos állampolgári attitűdöket, hogy generációkon átívelö, úgynevezett transztörténelmi értékek megőrzését is támogatja.

A kutatócsoport munkája a nemzetközi térben zajlik, eredményeink több tudományos konferencián és workshopon bemutatásra kerültek. ${ }^{1}$ Legfontosabb nem-

\footnotetext{
${ }^{1}$ Tudományos elöadásaink a Conference on Educational Assessment, a Hungarian Confer= ence on Education Research (4 előadás, 1 szimpózium), Országos Neveléstudományi Konferencia (6 előadás, 1 szimpózium) kereteiben hazai konferenciákon és az International Society for History Didactics (2018 Ottawa, 2019 Tutzing), valamint a European Educational Research Association által rendezett European Conference on Educational Research (2019 Hamburg) nemzetközi konferenciákon hangzottak el. Továbbá 2018-ban részt vettünk a University of Southern California Soah Foundation workshopján.
} 
zetközi szakmai partnerünk a USC Soah Foundation, továbbá a European Educational Research Association és az International Society for History Didactics konferenciái. A hazánkban általunk felvetett kérdések éppúgy foglalkoztatják a nemzetközi szakmai közösséget is, hiszen a történelemtanítás elött álló új kihívások a globális világban szinte mindenütt azonosak. A nemzetközi közösség az összehasonlító oktatáskutatás szempontjából a globális azonosságok mellett a glokális és a lokális specifikumok kapcsán is érdeklődik a téma iránt, például, hogy a hazai oktatási rendszer változásai miképpen reflektálnak ezekre az új kihívásokra.

A NAT formálódásával felerősödött az igény a történelemtanárok körében az új szempontokat figyelembe vevő, és az új kihívásokra, illetve tanári szerepelvárásokra gyakorlatorientált válaszokat felmutató képzésekre. Kutatási eredményeink alapján a Szegedi Tudományegyetemmel együttműködésben két tanártovábbképzés is született, egy harmincórás pedagógus továbbképzés és egy kétéves szakirányú továbbképzés. Az előbbiről már az első megvalósult képzés tapasztalatainak birtokában vagyunk, az utóbbi pedig az Országos Köznevelési Tanács Pedagógus-képzési és Továbbképzési Bizottsága támogatásával engedélyt kapott az Oktatási Hivataltól a 2020 őszétől való indításra.

Ezzel azonban a kutatócsoport munkája nem zárult le, további kutatási terven dolgozunk a tantárgy-pedagógiai kutatási tényeken alapuló módszertani fejlesztések folytatására, három új témában, új szempontok bevonásával, és - szintúgy, mint eddig - digitális videóinterjú-nyersanyagok tanórai alkalmazásával. A fő fókusz a történelmi és kritikai gondolkodás fejlesztésén lesz, a Kádár-rendszer hétköznapjai, illetve a magyarországi rendszerváltás tematikájában. Továbbá tervezzük egy határon átívelő kibeszéletlen eseménypár, az 1941. évi „hideg napok” és az 1944/45 fordulóján elkövetett délvidéki megtorlás feldolgozásában magyar és szerb nyelvü tanórák kifejlesztését és kutatási eredmények alapján történő tanórai alkalmazásának vizsgálatát, magyar-szerb munkacsoport létrehozásával.

A nemzetközi tudományos közösség, valamint a partnerpedagógusok és az iskolák visszajelzései alapján azt mondhatjuk, hogy a kutatási tényeken alapuló tantárgyfejlesztés terén az MTA Tantárgy-pedagógiai Programja igen fontos hozzáadott értéket képvisel a történelemtanítás 21. századi kihívásokra válaszokat felmutató, korszerü, ugyanakkor a hagyomány és modernitás szinergiáját felhasználó kutatásalapú megújításához. Az elmúlt időszakban kutatócsoportunk az MTA támogatásával ehhez járult hozzá tudományos eredményekkel és a pedagógustársadalom által ingyenesen elérhetô módszertani anyagok kifejlesztésével, amely munkát a fentiek szerint folytatni szeretnénk a jövőben.

A tanulmány elkészítését az MTA Tantárgy-pedagógiai Kutatási Programja támogatta. 


\section{IRODALOM}

Bage, G. (1999): Narrative Matters-Teaching and Learning History through Story. London: Falmer Press

Beck, U. (2007): Weltrisikogesellschaft, auf der Suhe nach der verlorenen Sicherheit. Frankfurt am Main: Suhrkamp

Fischerné D. Á. (2010): Történelemtanítás Magyarországon a XXI. század elején (Helyzetkép és perspektíva). Történelemtanitás, 1, 1, http://www.folyoirat.tortenelemtanitas.hu/2010/02/ fischerne-dardai-agnes-tortenelemtanitas-magyarorszagon-a-xxi-szazad-elejen-helyzetkep-es-perspektiva/ (Letöltve: 2019. 10. 12.)

Gábor K. (2012): Válogatott ifjúságszociológiai tanulmányok. Szeged: Belvedere Meridionale

Galán A. (2014): Az internetfüggőség kialakulása és prevalenciája: A hazai és nemzetközi kutatási eredmények összefoglalása. Metszetek, 3, 1, 316-327. http://metszetek.unideb.hu/ files/201401_17_galan_anita_1.pdf

Havekes, H. - Aardema, A. - de Vries, J. (2010): Active Historical Thinking: Designing Learning Activities to Stimulate Domain-specific Thinking. Teaching History, Jun, 52-59. https://www. researchgate.net/publication/294873729_Havekes_2010_Active_Historical_Thinking_Teaching_History

Husbands, C. (1996): What is History Teaching? Maidenhead: Open University Press

Husén, T. (1997): Teaching and/or Learning: Reform of Educational Structure and Modalities. In: Cummings, W. K. - McGinn, N. F. (eds.): International Handbook of Education and Development: Preparing Schools, Students, Nations for Twenty-First Century. Oxford: Pergamon, $173-183$.

Jancsák Cs. (2013): Ifjúsági korosztályok korszakváltásban. Budapest: Új Mandátum Könyvkiadó, https://www.academia.edu/10010634/Ifj\%C3\%BAs\%C3\%A1gi_koroszt\%C3\%A1lyok_korszakv\%C3\%A1lt\%C3\%A1sban

Jancsák Cs. (2018): Kutatási tényeken alapuló tananyagfejlesztés az MTA-SZTE Elbeszélt Történelem és Történelemtanítás Kutatócsoportban. In: Bánréti Z. - Jancsák Cs. - Kósa M. et al. (szerk.): Félidőben - Eredmények és perspektívák: MTA Tantárgy-pedagógiai Kutatási Program Bölcsészeti és Társadalomtudományi Munkacsoportjának konferenciája és szakmai vitája. Szeged: MTA-SZTE ETTK, 37-38. https://mta.hu/data/dokumentumok/ Tantargy-pedagogiai\%20program/Felidos\%20szakmai\%20beszamolok/Jancsak_Csaba_felidos_beszamolo.pdf

Jancsák Cs. (2019a): Value Crisis and Change of Values: In the Mirror of Social Values and History Education in Hungary. Hungarian Educational Research Journal, 9, 3, 565-568. DOI:10.1556/063.9.2019.4.59, https://akjournals.com/view/journals/063/9/3/article-p565.xml

Jancsák Cs. (2019b): Family Accounts, Narratives, Social Values and History Education. Belvedere Meridionale, 31, 4, 13-24. DOI: 10.14232/belv.2019.4.2, https://www.researchgate.net/ publication/340669786_Family_accounts_narratives_social_values_and_history_education

Kadriye, E. - Seixas, P. (2015): New Directions in Assessing Historical Thinking. New York: Routledge

Kaposi József (2017): Skills Development Tasks and the Development of Historical Thinking. In: Fehérvári A. (ed.): Curriculum, Effectiveness, Equity. Budapest, OFI, 9-22. https://ofi.oh.gov. $\mathrm{hu} /$ sites/default/files/attachments/curriculum_effectiveness_equity_1.pdf

Keating, J. - Sheldon, N. (2011): History in Education: Trends and Themes in History Teaching. In: Davies, I. (ed.): Debates in History Teaching. London: Routledge, 5-17.

Kelly, M. T. (2018): Teaching History in the Digital Age. Michigan: University of Michigan Press DOI: 10.3998/dh.12146032.0001.001, https://www.jstor.org/stable/j.ctv65swp1 
Kiss H. - Pikó B. (2018): Problémás okostelefon- és internethasználat középiskolás és egyetemista fiatalok körében - a veszélyeztetettség meghatározása klaszteranalízis alapján. Új Pedagógiai Szemle, 68, 5-6, 22-43. https://folyoiratok.oh.gov.hu/uj-pedagogiai-szemle/problemas-okostelefon-es-internethasznalat-kozepiskolas-es-egyetemista-fiatalok

Körber, A. (2011): German History Didactics: From Historical Consciousness to Historical Competencies - and Beyond? In: Bjerg, H. - Lenz, C. - Thorstensen, E. (eds.): Historicizing the Uses of the Past: Scandinavian Perspectives on History, Culture, Historical Consciousness and Didactics of History Related to World War II. New Brunswick NJ: Transaction Publishers, 145-164. DOI: 10.14361/transcript.9783839413258.145, https://www.degruyter.com/view/ book/9783839413258/10.14361/transcript.9783839413258.145.xml

M. Fazekas Á. - Cs. Czachesz E. (2011): Középiskolás tanulók számítógép- és internethasználati szokásai. Iskolakultúra, 8-9, 120-134. http://real.mtak.hu/56845/

Maggioni, L. (2010): Studying Epistemic Cognition in the History Classroom: Cases of Teaching and Learning to Think Historically. (Doctoral dissertation) https://www.researchgate.net/publication/271429471

Megill, A. (1994): Jörn Rüsen's Theory of Historiography: Between Modernism and Rhetoric of Inquiry. History and Theory, 31, 1, 39-60. DOI: 10.2307/2505651

Metzger, S. A. - McArthur, H. L. (eds.) (2018): The Wiley International Handbook of History. Teaching and Learning. New York: Wiley-Blackwell, 283-309.

Seixas, P. (2016): A History/Memory Matrix for History Education. Public History Weekly, 4, 6, DOI: $10.1515 / \mathrm{phw}-2016-5370$, https://www.researchgate.net/publication/317802699_A_HistoryMemory_Matrix_for_History_Education

Székely L. - Szabó A. (szerk.) (2017): Ezek a mai magyar fiatalok! (Magyar Ifjúság Kutatás) Budapest: Új Nemzedék Központ Nonprofit Kft. https://ujnemzedek.hu/sites/default/files/atoms/ files/magyar_ifjusag_2016_a4_web_0.pdf

Tally, B. - Goldenberg, L. B. (2005): Fostering Historical Thinking with Digitized Primary Sources. Journal of Research on Technology in Education, 38, 1, 1-21. DOI: 10.1080/15391523.2005.10782447, https://files.eric.ed.gov/fulltext/EJ719935.pdf

Wineburg, S. (2001): Historical Thinking and Other Unnatural Acts: Charting the Future of Teaching the Past. Temple UP, http://www.socialstudies.org/sites/default/files/publications/ se/6505/650508.html

Zsolnai A. (2017): A média hatása a szociális viselkedésre és a társas kapcsolatok alakulására serdülökorban. Educatio, 26, 2, 246-256. DOI: 10.1556/2063.26.2017.2.7, http://real.mtak. $\mathrm{hu} / 80959 /$ 